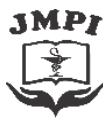

Jurnal Mandala Pharmacon Indonesia, Vol 5.No.1 Juni 2019

Avaiable online at www.jurnal-pharmaconmw.com/jmpi

$p$-ISSN : 2442-6032

$e$-ISSN : 2598-9979

\title{
Formulasi Pasta Gigi Herbal Ekstrak Daun Sukun (Artocarpus altilis) Dan Uji Aktivitas Antibakteri Terhadap bakteri Streptococcus mutans
}

\author{
Wa Ode Yuliastri, Mus Ifaya, Mulyadi Prasetyo \\ Program Studi Farmasi STIKES Mandala Waluya Kendari
}

\begin{abstract}
ABSTRAK
Prevalensi karies di Indonesia pada tahun 2013 berkisar $72,3 \%$. Karies gigi yang disebabkan oleh bakteri Streptococcus mutans dapat dihindari dengan bantuan senyawa kimiawi maupun tindakan mekanis. Pengunaan bahan alternatif dari bahan alam dalam sediaan pasta gigi sedang dikemabangkan. Salah satu tanaman yang dapat digunakan adalah daun sukun (Artocarpusaltilis). Jenis penelitian ini adalah penelitian eksperimental laboratorium. Pada pembuatan sediaan pasta gigi herbal ekstrak daun sukun dibuat 3 formula dengan konsentrasi ekstrak masing-masing 10\%, 15\% dan 20\%. Penelitian ini menggunakan uji ANOVA (Analysis of Variance) untuk melihat perbedaan signifikan dari masing-masing perlakuan. Hasil penelitian menunjukkan hasil pengujian evaluasi fisik yang palik baik adalah formula III. Pada pengujian aktivitas antibakteri diperoleh daya hambat paling baik pada pasta gigi herbal adalah formula 3 dengan rata-rata luas daya hambat

sebesar 21,37mm yang dapat dikategorikan memiliki daya hambat yang sangat kuat. Hasil uji ANOVA juga diperoleh nilai $p<0,005$ yang menunjukkan adanya perbedaan signifikan dari masing-masing konsentrasi. Sediaan pasta gigi herbal ekstrak daun sukun (Artocarpusaltilis) dapat disimpulkan bahwa pembuatan sediaan pasta gigi herbal stabil pada evaluasi fisik dan memiliki aktivitas antibakteri terhadap bakteri Streptococcus mutans.

Kata kunci : Antibakteri, Pasta Gigi Herbal, Daun Sukun

\section{Penulis korespondensi :}

Wa Ode Yuliastri

Program Studi Farmasi STIKES Mandala Waluya

Kendari

E-mail : waodeyuliastri@yahoo.co
\end{abstract}

\section{PENDAHULUAN}

Berdasarkan data Riset Kesehatan Dasar (2013), Kasus karies gigi di indonesia terjadi peningkatan. Pada tahun 2007, penderita karies gigi aktif meningkat dari angka $43,4 \%$ sebesar 9,8\% menjadi 53,2\%, sedangkan penderita pengalaman karies meningkat $5,1 \%$ dari $67,2 \%$ pada tahun 2007 naik menjadi 72,3\% pada tahun 2013.

Salah satu penyebab karies gigi adalah bakteri Streptococcus mutans. Streptococcus mutans mrupakan bakteri gram positif yang memiliki kemampuan mengubah karbohidrat menjadi asam laktat. Peningkatan konsentrasi asam laktat bertanggungjawab ppada demineralisasi email ketika saliva tidak mampu mencegah larutnya email,selanjutnya proses karies dapat terjadi (Madigan, 2009).

Karies gigi yang disebabkan oleh bakteri Streptococcus mutans dapat dicegah dengan bantuan senyawa kimiawi maupun tindakan mekanis. Tindakan mekanis antara lain dengan Menyikat gigi dengan menggunakan sikat gigi untuk menyingkiran plak. Menyikat gigi dengan menggunakan 
pasta gigi maka pembersihan plak dilakukan secara mekanis dan kimiawi. Saat ini fluoride merupakan bahan utama dalam pasta gigi yang digunakan untuk mencegah karies pada gigi, tetapi diketahui bahwa penggunaan fluoride secara terus menerus dan dalam jumlah besar dapat menimbulkan beberapa efek samping seperti tulang rapuh, gigi keropos, aborsi spontan, fluorosis email irreversible, penuaan dini, dan bersifat karsinogenik (Mason, 2000).

Penggunaan bahan alam sebagai bahan alternatif perlu dikembangkan untuk membuat sediaan pasta gigi yang sehat. Salah satu tanaman yang bisa dimanfaatkan adalah daun sukun (Artocarpusaltilis). Kandungan metabolit sekunder dari daun sukun antara lain senyawa flavonoid, fenol, alkaloid, dan tanin. Metabolit sekunder yang telah terbukti sebagai antibakteri antara lain senyawa flavonoid, alkaloid, fenol dan tanin. Flavovoin dan tanin merupakan bahan aktif yang dapat bersifat sebagai antibakteri dengan mekanisme kerja menghambat metabolisme bakteri, sedangkan saponin berfungsi untuk merusak protein dinding sel bakteri. (Rosmawaty dan Hellna, 2013).

Berdasarkan Penelitian Ghazalah (2013), ekstrak daun sukun pada konsentrasi 10\% dapat memberikan aktivitas antibakteri terhadap bakteri Streptococcus mutans dengan luas zona hambatan sebesar 7,5mm. Penelitian ini dilakukan untuk memanfaatkan daun sukun yang masih sangat kurang diberdayakan, menjadi sediaan pasta gigi herbal yang berkualitas, aman dan sehat sesuai dengan SNI sediaan pasta gigi (Suryanto $\mathrm{dkk}, 2009)$.

Oleh karena itu penulis tertarik untuk melakukan penelitian tentang "Formulasi Pasta Gigi Herbal Ekstrak Daun Sukun (Artocarpusaltilis) Dan Uji Aktivitas Antibakteri Terhadap Bakteri Streptococcus mutans".

\section{METODE PENELITIAN}

\section{Alat dan Bahan}

Alat yang digunakan adalah mortar dan stamper, $\mathrm{pH}$ meter, rotaryevaporator, seperangkat alat maserator, termometer, timbangan digital(OHAUS $\left.{ }^{\circledR}\right)$, Viscometer, antibiotik zone reader, autoklaf, batang pengaduk, cawan petri, Inkubator, jarum ose, kain flannel, kapas, lampu spritus, oven, pingset, pisau.

Bahan yang digunakan adalah air suling, DMSO,daun sukun, etanol dan 96\%, menthol, kalsium karbonat, natrium $\mathrm{CMC}, \mathrm{NaCL}$, natrium benzoat, sodium lauril sulfat, saccharin, sorbitol, media NA, Isolat Streptococcus mutans yang merupakan biakan dari Laboratorium Mikrobiologi Prodi Farmasi STIKES Mandala Waluya.

\section{PROSEDUR PENELITIAN}

\section{Prosedur Ekstraksi}

Ditimbang simplisia daun sukun 50og lalu dimasukkan kedalam bejana maserasi, ditambahkan pelarut etanol 70\% sebanyak 375omL, diaduk lalu ditutup rapat bejana maserasi, dimaserasi selama $3 \times 24$ jam disimpan pada suhu kamar terlindung dari cahaya, dengan perlakuan tiap hari diaduk setiap 3-4 jam dalam sehari, disaring menggunakan kain flannel, Maserat ditampung dalam botol lalu dipekatkan dengan menggunakan rotary evaporator hingga diperoleh ekstrak kental, setelah kental dimasukkan kedalam wadah yang sesuai.

\section{Prosedur Pembuatan Pasta Gigi}

NaCMC didispersikan dalam air suling. Menthol dilarutkan dalam metanol. Natrium benzoat dilarutkan dalam air suling. Ekstrak diencerkan dengan etanol, lalu ditambah sorbitol dan larutan mentol. Ditambahkan dispersi NaCMC, kalsium karbonat dan larutan natrium benzoat. Ditambahkan Sodium Lauril sulfat dan saccharin kemudian diaduk sampai homogen. Formula sediaan pasta gigi dapat dilihat pada tabel 1. 
Tabel 1. Tabel Formula Sediaan Pasta Gigi

\begin{tabular}{|c|c|c|c|c|}
\hline \multirow{2}{*}{ Nama Bahan } & \multirow{2}{*}{ Fungsi } & \multicolumn{2}{|c|}{ Formula (\%) } & \multirow[b]{2}{*}{$\mathrm{C}$} \\
\hline & & $\mathrm{A}$ & $\mathrm{B}$ & \\
\hline $\begin{array}{l}\text { Ekstrak etanol } \\
\text { daun sukun }\end{array}$ & Bahan aktif & 10 & 15 & 20 \\
\hline $\mathrm{Na} \mathrm{CMC}$ & Basis Pasta & 2 & 2 & 2 \\
\hline Sorbitol & Humectants & 30 & 30 & 30 \\
\hline Menthol & Pengaroma & 0,5 & $\overline{0,5}$ & 0,5 \\
\hline Natrium benzoat & Pengawet & 0,5 & 0,5 & 0,5 \\
\hline Sodium Lauril Sulfat & Surfaktan & 2 & 2 & 2 \\
\hline Sodium Saccharin & Pemanis & 0,12 & 0,1 & 0,12 \\
\hline Calcium Carbonat & Abrasive & 30 & 30 & 30 \\
\hline Etanol 95\% & Pelarut & 3 & 3 & 3 \\
\hline Air suling ad & Pelarut & $100 \%$ & $100 \%$ & $100 \%$ \\
\hline
\end{tabular}

\section{Pembuatan Suspensi Bakteri}

Streptococcus mutans diinokulasi satu ose pada media yang telah disterilkan, kemudian diinkubasikan pada suhu $35^{\circ} \mathrm{C}-37^{\circ} \mathrm{C}$ selama 18 - 24 jam, biakkan dibilas dengan $3 \mathrm{ml} \mathrm{NaCl}$ $0,9 \%$, suspensi dipindahkan kedalam $250 \mathrm{ml}$ media di dalam erlenmeyer dan diinkubasi pada suhu $35^{\circ} \mathrm{C}-37^{\circ} \mathrm{C}$ selama 24 jam, biakkan dalam erlenmeyer dibilas dengan $\pm 50 \mathrm{ml} \mathrm{NaCl}$ 0,9\%, biakkan siap digunakan sebagai suspensi induk bakteri uji.

Pengujian Diameter Zona Hambat Pasta Gigi Herbal Ekstrak Daun Sukun Terhadap Pertumbuhan Bakteri Streptococcus mutans dengan Metode Paper disk.

Disiapkan media NA steril yang telah telah dicairkan dan dibiarkan suhunya hingga $50-60^{\circ} \mathrm{C}$, kemudian ditambahkan $1 \mathrm{ml}$ suspensi bakteri uji, campur media hingga homogen (Inokulum), dipipet sebanyak $20 \mathrm{ml}$ media NA kemudian dituang ke dalam cawan petri dan dibiarkan memadat. Kemudian dimasukan Paper diskke dalam suspensi ekstrak pasta gigi herbal dengan kosentrasi $10 \%$, $15 \%$ dan $20 \%$, lalu dimasukkan pula paper disk pada kontrol (+) dan kontrol (-) DMSO. Setelah itu paper disk dimasukkan didalam cawan petri yang berisi media yang telah memadat. Diinkubasi selama 24 jam pada suhu $35^{\circ} \mathrm{C}-37^{\circ} \mathrm{C}$ dalam inkubator, keluarkan dari inkubator dan diamati luas daerah hambatan pertumbuhan bakteri. Diukur zona hambat yang terjadi dengan alat antibiotic zona reader (pengukur zona hambat).

\section{HASIL PENELITIAN \\ Uji pH}

Tabel 2.Hasil pengujian $\mathrm{pH}$ sediaan

\begin{tabular}{cccc}
\hline \multirow{2}{*}{ Minggu ke- } & \multicolumn{3}{c}{$\mathbf{p H}$} \\
\cline { 2 - 4 } & F I & F II & F III \\
\hline 1 & 7 & 7 & 7 \\
\hline 2 & 7 & 7 & 7 \\
\hline 3 & 7 & 7 & 7 \\
\hline 4 & 7 & 7 & 6 \\
\hline
\end{tabular}




\section{Uji Organoleptik}

Tabel 3. Hasil uji organoleptik sediaan berdasarkan bentuk,bau dan warna sediaan.

\begin{tabular}{|c|c|c|c|c|c|c|c|c|c|}
\hline \multirow{2}{*}{ Minggu } & \multicolumn{3}{|c|}{ Formula I } & \multicolumn{3}{|c|}{ Formula II } & \multicolumn{3}{|c|}{ Formula III } \\
\hline & Bentuk & Bau & Warna & Bentuk & Bau & Warna & Bentuk & Bau & Warna \\
\hline \multirow{2}{*}{ I } & Semi & Khas & Hijau & Semi & Khas & Hijau & \multirow{2}{*}{ Semi Padat } & Khas & Hijau \\
\hline & Padat & Menthol & Muda & Padat & Menthol & Muda & & Menthol & Tua \\
\hline \multirow{2}{*}{ II } & Semi & Khas & Hijau & Semi & Khas & Hijau & \multirow{2}{*}{ Semi Padat } & Khas & Hijau \\
\hline & Padat & Menthol & Muda & Padat & Menthol & Muda & & Menthol & Tua \\
\hline \multirow{2}{*}{ III } & Semi & Khas & Hijau & Semi & Khas & Hijau & \multirow{2}{*}{ Semi Padat } & Khas & Hijau \\
\hline & Padat & Menthol & Muda & Padat & Menthol & Muda & & Menthol & Tua \\
\hline \multirow{2}{*}{ IV } & Semi & Khas & Hijau & Semi & Khas & Hijau & \multirow{2}{*}{ Semi Padat } & Khas & Hijau \\
\hline & Padat & Menthol & Muda & Padat & Menthol & Muda & & Menthol & Tua \\
\hline
\end{tabular}

\section{Uji Homogenitas}

Tabel 4. Hasil uji homogenitas sediaan berdasarkan lama penyimpanan

\begin{tabular}{cccc}
\hline $\begin{array}{c}\text { Minggu } \\
\text { ke- }\end{array}$ & \multicolumn{3}{c}{ Homogenitas } \\
\cline { 2 - 4 } $\mathbf{1}$ & F I & F II & F III \\
\hline $\mathbf{2}$ & Homogen & Homogen & Homogen \\
\hline 3 & Homogen & Homogen & Homogen \\
\hline 4 & Homogen & Homogen & Homogen \\
\hline
\end{tabular}

\section{Uji Viskositas}

Tabel 5. Hasil uji viskositas sediaan berdasarkan lama penyimpanan

\begin{tabular}{cccc}
\hline Minggu & \multicolumn{3}{c}{ Viskositas (dPa-s) } \\
\cline { 2 - 4 } ke- & F I & F II & F III \\
\hline 1 & 450 & 510 & 450 \\
\hline 2 & 440 & 460 & 460 \\
\hline 3 & 450 & 390 & 440 \\
\hline 4 & 460 & 440 & 460 \\
\hline
\end{tabular}

\section{Uji Cycling Test}

Pada uji cycling test sediaan tetap stabil baik dari segi organolepik, homogenitas, $\mathrm{pH}$ dan Viskositasnya.

\section{Uji Aktivitas Antibakteri}

Tabel 6. Hasil uji aktivitas antibakteri pada sediaan pasta gigi herbal ekstrak daun sukun (Artocarpus altilis)

\begin{tabular}{|c|c|c|c|c|}
\hline \multirow{2}{*}{ Perlakuan } & \multicolumn{3}{|c|}{ Zona Hambat(mm) } & \multirow{2}{*}{$\begin{array}{c}\text { Rata-Rata } \\
\text { Zona } \\
\text { Hambat } \\
(\mathbf{m m})\end{array}$} \\
\hline & $\mathbf{I}$ & II & III & \\
\hline $\mathrm{F} 1$ & 10,57 & 12 & 14,75 & 12.44 \\
\hline F2 & 15,5 & 17,65 & 15,54 & 16.23 \\
\hline F3 & 20,25 & 21.9 & 21.97 & 21.37 \\
\hline $\mathrm{F} 4$ & 23.05 & 22.02 & 22.09 & 22.38 \\
\hline $\mathrm{F} 5$ & 0 & $\mathrm{O}$ & $\mathrm{O}$ & $\mathrm{O}$ \\
\hline
\end{tabular}




\section{PEMBAHASAN}

Pada pengujian $\mathrm{pH}$ sediaan pasta gigi herbal ekstrak daun sukun, diperoleh nilai $\mathrm{pH}$ ketiga formula stabil dan sesuai dengan standar $\mathrm{pH}$ sediaan pasta gigi, dimana $\mathrm{pH}$ SNI pasta gigi adalah 4,5-10,5.Pada pengujian organoleptik diperoleh hasil ketiga formula sediaan homogen dan tetap stabil dari segi konsistensi, warna dan bau selama waktu penyimpanan.

Pada pengujian viskositas diperoleh ketiga formula berubah-ubah nilai viskositasnya hal ini dipengaruhi oleh temperatur atau suhu, Viskositas sediaan berhubungan dengan daya alir sediaan sesuai yang dipersyaratkan dalam sediaan tersebut. Walaupun tidak stabil namun viskositas ketiga formula tetap pada standar viskositas sediaan pasta gigi, yaitu 200-500 dPa-s.Pada uji cycling test ketiga formula tetap stabil dan tidak mengalami perubahan yang begitu signifikan dimana ketiga forma tetap stabil baik dari segi oragnoleptik, homogenitas, $\mathrm{pH}$ dan viskositasnya.

Pengujian aktivitas antibakteri pada sediaan pasta gigi herbal yang dibuat, diperoleh hasil rata-rata luas daya hambat pada formula I sebesar $12.44 \mathrm{~mm}$, pada formula II sebesar $16.23 \mathrm{~mm}$ dan formula III sebesar $21.37 \mathrm{~mm}$. Dari hasil tersebut dapat dikatakan bahwasanya ketiga formula tersebut memiliki aktivitas antibakteri, dimana formula I dan II dikategorikan memiliki daya hambat yang kuat dimana daya hambat lebih dari 10 $\mathrm{mm}$, sedangkan formula III dapat dikategorikan memiliki daya hambat yang sangat kuat dimana daya hambat lebih dari 20 mm, menurut Sally (2016). Dimana kandungan zat aktif pada daun sukun yang berfungsi sebagai zat antibakteri adalah flavonoid dan tanin.

Dari hasil uji ANOVA diperoleh hasil $p<$ 0,05 yang berarti terdapat perbedaan signifikan dari masing-masing perlakuan pada uji aktivitas antibakteri sediaan pasta gigi herbal daun sukun (Artocarpus altilis) terhadap bakteri Staphylococcus mutans.

\section{KESIMPULAN}

1. Ekstrak daun sukun dapat diformulasikan menjadi sediaan pasta gigi herbal antibakteri yang memenuhi syarat uji evaluasi fisik, yang meliputi pengujian $\mathrm{pH}$, homogenitas, organoleptik, viskositas, dan cycling test.

2. Sediaan pasta gigi herbal ekstrak daun sukun memiliki aktivitas antibakteri pada bakteri Streptococcus mutans, dimana sediaan pasta gigi yang memiliki aktivitas antibakteri paling baik yaitu pasta gigi dengan konsentrasi ekstrak 20\%.

\section{DAFTAR PUSTAKA}

Madigandkk,,2009.BiologyofMicroorganisms. $12^{\text {th }}$ ed.,PrenticeHall Intern., New York.

Mason, S., 2000. DentalHygiene, dalam:Butler, H. (Ed.), Poucher's Perfume,Cosmetics and Soap. Kliwe Academy Publishers, The Netherlands.

Rosmawaty dan Hellna Tehubijuluw,2013.Screening of Phytochemicalsand BioactivityTest of TheLeaves Bread fruit (Artocarpusaltilis), Ind.J. Chem.

Sally, L., Fatimawali., Wulan, G., 2016. Uji Daya Hambat Ekstrak Daun Sukun (Artocarpus altilis) Terhadap Pertumbuhan Bakteri Streptococcus Mutans. Universitas sam ratulangi Manado.

Suryanto,EdidanFrenlyWehantouw,2009.Akti vitasPenangkapRadikal

BebasdariEkstrakFenolikDaunSukun( ArtocarpusaltilisF.),Chem.Prog., 2(1).

Thifal, Ghazalah., 2016. Pengaruh pasta gigi ekstrak daun sukun (artocarpus altilis) Terhadap hambatan pertumbuhanstreptococcus mutans. Universitas muhammadiyah Surakarta. 